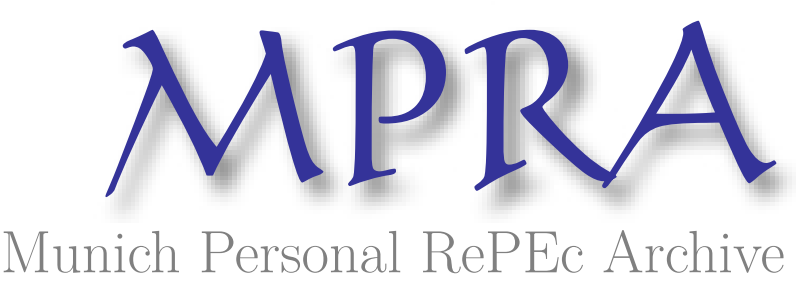

\title{
Ecosystem services of Bulgarian agriculture
}

Bachev, Hrabrin

5 January 2021

Online at https://mpra.ub.uni-muenchen.de/105437/

MPRA Paper No. 105437, posted 22 Jan 2021 05:56 UTC 


\title{
Ecosystem Services of Bulgarian Agriculture
}

\author{
Hrabrin Bachev ${ }^{1}$
}

\begin{abstract}
Agricultural ecosystems of different types and their specific "agroecosystem" services are among the most widespread in the world. However, in Bulgaria the state of practical progression of the studies of agricultural services in mostly at the methodological level and very limited to general classification and qualitative "assessments". This article tries to fill the gap and present initial results of large scale studies on the structure and importance of agroecosystem services in Bulgaria. The identification of the type, size, efficiency and importance of "produced" services of agro-systems is based on the assessments of the managers of 324 "typical" farms of different legal status, size, production specialization, ecological and geographical location. The study has found out that there are significant differences in the participation and contribution of agricultural holdings in the protection and provision of agro-ecosystem services in the various specific and principled ecosystems of the country, and major subsectors of agricultural production. The latter requires special measures to improve, diversify and intensify this activity of farmers through training, information, exchange of experience, public incentives and support, etc. Analyzes of the structure and importance of agro-ecosystem services in the country are to be expanded by improving the accuracy and representativeness of the information by increasing the number of surveyed farms, avoiding "double" accounting, applying statistical methods to verify the reliability, special "training" of and those involved in surveys, applying direct field measurements experts and stakeholders involvement etc.
\end{abstract}

Key words: ecosystem services, agriculture, ammount, structure, importance, Bulgaria

\footnotetext{
${ }^{1}$ Institute of Agricultural Economics, Sofia, E-mail: hbachev@yahoo.com
} 


\section{Introduction}

The products and the variety of direct and indirect benefits that humans receive from nature and the various ecosystems (agricultural, forest, grass, desert, rural, urban, mountain, lake, river, marine, coastal, etc.) are commonly known as "ecosystem services" (MEA). Agricultural ecosystems of different types and their specific "agro-ecosystem" services are among the most widespread in the world (EEA; FAO; INRA; UN). That is why the „new“ term agroecosystem "services" and "diservices" have been rapidly introduced in academic studies, and policies and business practices around the globe (Boelee; De Groot et al.; Fremier et al.; EEA; FAO; Gao et al.; Garbach et al.; Habib et al.; Kanianska; MEA; Nunes et al.; Novikova et al.; Marta-Pedroso et al.; Petteri et al.; Power; Scholes et al.; Tsiafouli et al.; Van Oudenhoven; Wang et al.; Wood et.al.; Zhan). Nevertheless, in Bulgaria, like in many other countries, the studies associated with the agricultural contribution to ecosystem services of different type are at the beginning stage (Башев; Башев и др.; Казакова; Недков; Николов; Тодорова; Bachev; Grigorova and Kazakova; Todorova, ИАОС; Йорданов и др.; Чипев и др.).

Following the modern trends, huge degradation of (agro)ecosystems, and the "greening" of European Union policies (EC), official maping of ecosystem services in Bulgaria has been initiated in recent years (ИАОС). However, up to date the state of practival progression of the studies of agricultural services in the country is mostly at methodological level and very limited to general qlasification and qualitative "assessments" (ИАОС; Башев и др.; Bachev). Simultanously, there is a growing demands by farm manegers, policy makers, interests groups, public at large, etc. and needs for identification of scope, ammount and importance of diverse ecosystem services provided by country's agriculture.

This article tries to fill the gap and present initial results of a large scale studies on the structure and imporance of agroecosystm services in Bulgaria. 


\section{Methods and data}

A modern framework for understaning and classification of agroecosysem services has been incorporated dividing them into different type - provisional (food for humans and animals, materials and resources for production and livelihoods, etc.), economic, a place for human life and activity, recreational, tourist, aesthetic, cultural, educational, informational, habitat, supporting, biodiversity conservation, water purification and retention, flood and fire protection, climate regulation, etc. (ИАОС; МЕA).

By definition, ,agrarian“ ecosystems and ,agrarian“ ecosystem services are understood as ecosystem services related to agrarian (farming) ,production“, which as a rule is human (social) intervention in the natural order of nature. The hierarchy of agro-ecosystems and their services include multiple levels - from individual agricultural land plot/section, to land area, micro region etc. (Figure 1). Indivial farm is the main organizational unit in agriculture that manages resources, technologies and activities and produces a variety of products, including the positive and negative services of agro-ecosystems (Башев; Bachev). The governance of agro-ecosystem services is an integral part of the management of agricultural farm, and the farm - the first (lowest) level for agro-ecosystem services management ${ }^{2}$.

\section{Figure 1. Hierarchy of Agro-ecosystems in Bulgaria}

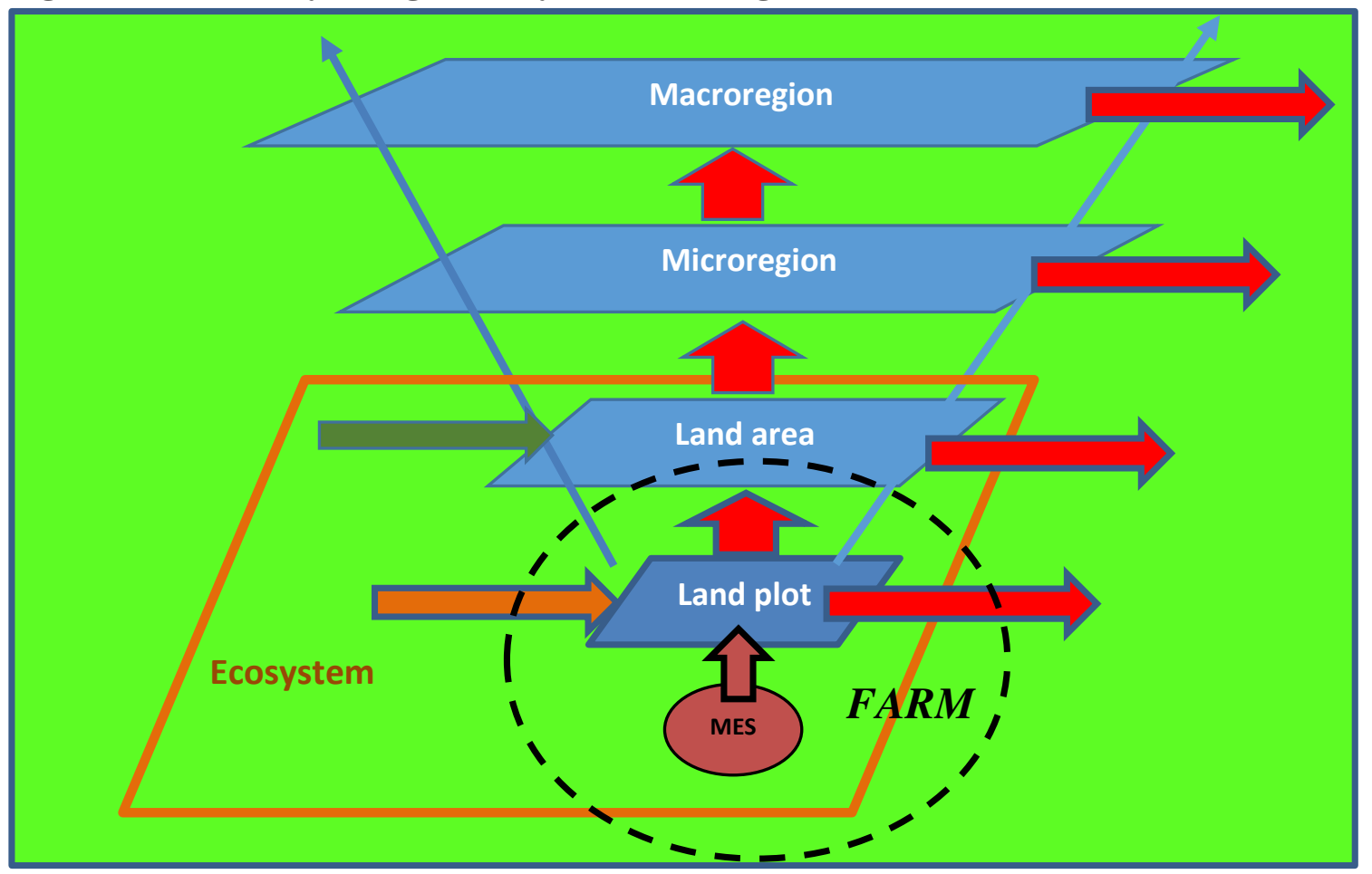

Blue - agro-ecosystem, Red - Agroecosystem Services, MES - Micro ecosystem located in the land plot, Green - Services of non-agrarian ecosystems, Dash area - Borders (activity) of individual farm Source: author

In Bulgaria there is no available statisctical and other data on services provided by different type of agroecosystems. Since the individual farm is the basic unit of management of agrarian activities and provision of agro-ecostsem services, our study has focused on the (individual) farm level of maintainance and supply of ecosystem services. The agroecosystem services at a higher lever are evaluated as sum of agroecosystem services provided by the farms

\footnotetext{
${ }^{2}$ Farm borders rarely coincide with the (agro) ecosystem boundaries (Bachev).
} 
associated with the relevant (agro)ecosystems. Concequently, there is an unavoidable error from double accouning and/or uncalculated trade offs, sinergies, complementarities and contervercies of analised agroecosystem services of different type.

Literature review, experts opition and pilot studies have been used to identify the list of likely agroecosystem services maintained and supplied by agricultural farms in Bulgaria, and an option left for adding existing unlisted service(s).

The identification of the type, size, efficiency and importance of "produced" services of agro-systems is based on the assessments of the managers of 324 "typical" farms of different legal status, size, production specialization, ecological and geographical location. The survey was conducted in October 2020 with the assistance of the National Agricultural Advisory Service and leading professional organizations of agricultural producers in the country. Surveyed farms account for almost $0,5 \%$ of all registered agricultural producers in the country. The structure of studied holdings aproximately correspond to the real structure of farms in Bulgaria.

The accessments of the farm manares about type, ammount, and importance of agroecosystem services they maintain or prodice give good insights on the state and efficiency of agrpecosystem services in the country. The assimetry of information is quite big in the area and farmers are among the most informed actors about agricultural efforts and contribution toward (agro)ecosystem services. However, the managers estimates also reflects the "personal" (subjecive) knowlege and perceptions of the farmers on agroecosystem services, and their values, the efforts rather than output and impacts, etc. The objectivity of the study would partialy increasy during the next stage of the study when farmers assessments will be complemented with estimates of stakeholders, consumers, experts, etc. 


\section{Type and Ammount of Agroecosystem Services}

The conducted survey allowed to make a detailed map of the agro-ecosystem services of different types provided by agricultural producers, as well as to determine the structure and volume of the services of the agro-ecosystems of various types. The share of farms involved in activities related to the provision of agro-ecosystem service of a certain kind gives a good idea of the volume of "produced" service of that type.

The majority of Bulgarian farms participate in the "Production of products (fruits, vegetables, flowers, etc.) for direct human consumption" (59.3\%), which is one of the main "services" of agro-ecosystems in the country (Figure 2). A significant part of the farms also "Produce raw materials (fruits, milk, etc.) for the food industry" (15.4\%). Other "production" services in which a smaller part of the farms participate are "Production of animal feed" $(8.6 \%)$, "Own processing of agricultural products" (6.17\%), "Production of seeds, saplings, animals, etc. for farms" $(4.3 \%)$ and "Production of raw materials for cosmetic, textile, energy, etc. industry" $(3.09 \%)$.

Other "production" services of agroecosystems, in which a relatively small part of agricultural producers participate, are "Provision of services to other farms and agricultural organizations" (2.47\%), "Provision of services to end users (riding, fruit picking, etc.)" (1.85\%), "Provision of tourist and restaurant services" (0.62\%) and "Production of bio, wind, solar, etc. energy" $(0.62 \%)$.

Other important services of the agro-ecosystems, in which "supply" a large part of the agricultural holdings participate, are "Hiring workers" (11.11\%) and "Providing free access on the farm to outsiders" (10.49\%).

Relatively many of the farms are also involved in the protection and preservation of technological, biological, cultural and other heritage - "Preservation of traditional crops and plant varieties" (6.17\%), "Preservation of traditional species and breeds of animals" (7.41\%), "Preservation of traditional methods, technologies and crafts" (6.17\%), "Preservation of traditional products" (6.17\%), "Preservation of traditional services" (5.55\%), "Preservation of traditions and customs" (3.7\%) and "Preservation of historical heritage" (1.23\%).

A major part of agro-ecosystem services consists in preserving, restoring and improving the elements of the natural environment - soil, water, air, gene pool, landscape, plants and animals, etc. The activity of a large part of the agricultural holdings is aimed at the production of this type of agro-ecosystem services - "Disease control (measures)" (24.69\%), "Pest control (measures)" (19.75\%), "Protection of natural biodiversity" (18.52\%), "Protection and improvement of soil fertility" (16.67\%), "Protection from soil erosion" (13.58\%), "Protection and improvement of soil purity" (12.34\%), "Protection of surface water" (11.73\%), "Protection of groundwater purity" (9.88\%), "Ffire protection (measures)" (8.64\%), and "Protection of plant and/or animal gene pool" $(8.02 \%)$.

A relatively smaller part of the farms are also included in "(Measures for) water conservation and saving" (5.55\%), "(Measures for) regulation of the correct outflow of water" (4.32\%), "Preservation of air quility" (4.32\%), "Preservation of traditional scinery and landscape" (3.7\%), "Improvement (aesthetics, aroma, land use, etc.) of scinery and landscape "(3.09\%), "(Measures for) regulation and improvement of the microclimate" (3.09\%), "Flood protection (measures)" (2.47\%), and "Greenhouse gas emission reduction (measures)" $(2.47 \%)$, and "(Measures) for storm protection" (1.85\%). 
One of the essential services of agroecosystems is the recovery and recycling of "waste" from various activities in the sector and other industries. The main activity of many farms in this regard is "Use of manure on the farm" (13.58\%), and to a lesser extent "Reuse and recycling of waste, composting, etc." (3.09\%) and "Use of sludge from water treatment on-farm" $(0.62 \%)$.

Agri-ecosystems also make a significant contribution to training farmers and nonagricultural agents, conducting scientific experiments, demonstrating innovation, and so on. In such educational, scientific and innovative services participate a smaller part of the agricultural producers - "Training and advice of other farmers" (4.32\%), "Training of students, consumers, etc." $(1.85 \%)$, "Demonstration of production, technologies, innovations, etc." $(1.85 \%)$ and "Conducting a scientific experiment"(1.85\%).

Agroecosystems also contribute to the "Protection and improvement of non-agricultural (forest, lake, urban, etc.) ecosystems" with $4.32 \%$ of farms in the country engaged in such efforts. 


\section{Figure 2. Share of farms participating in (supporting) the preservation or production of different types of agro-ecosystem services in Bulgaria (percentages)}

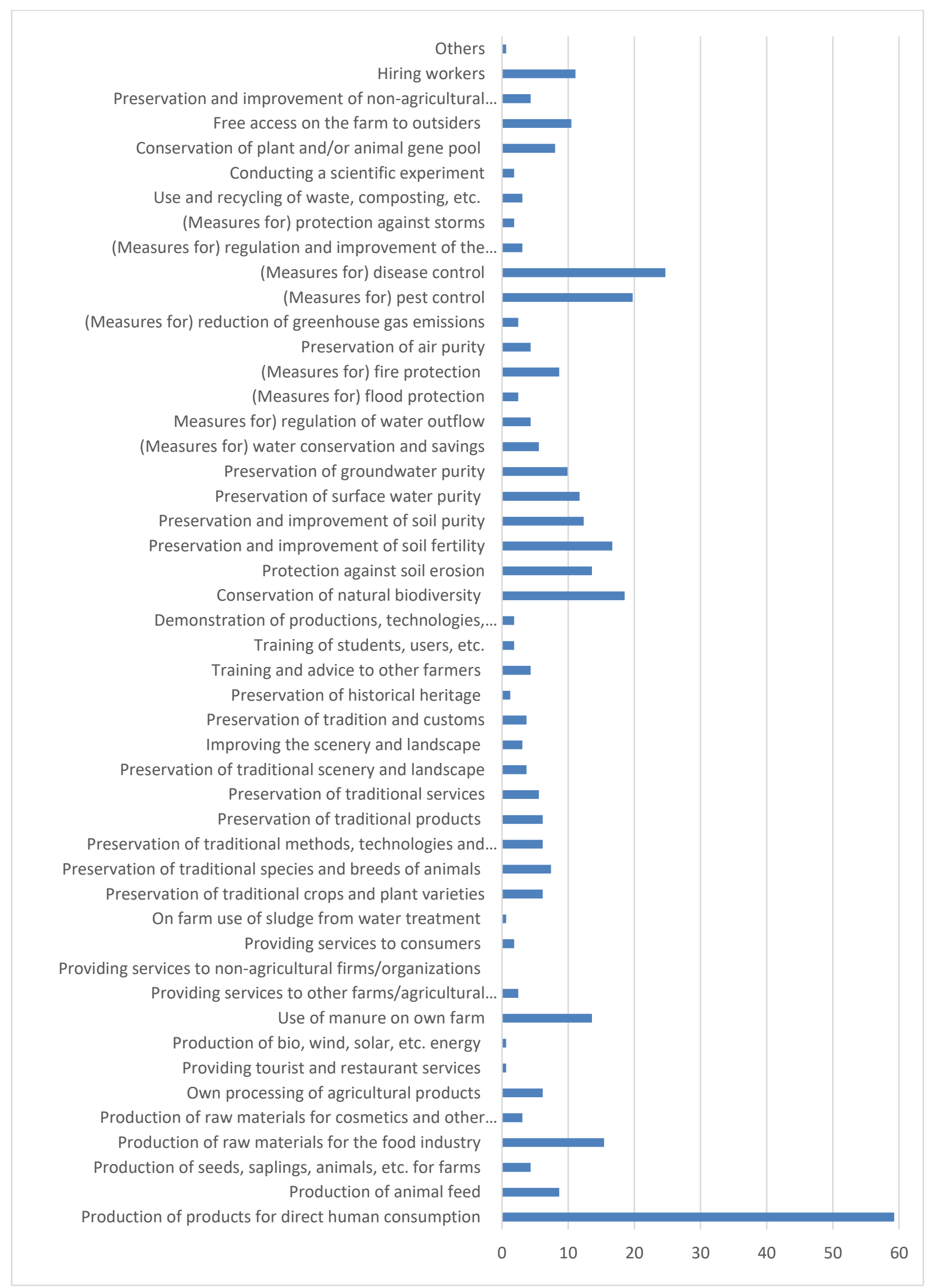

Source: Survey of agricultural producers, 2020 
The extent of participation of supplying farms in the presevation or production of agroecosystem services is not equal. For most agri-ecosystem services, the holdings involved in the activities do so "To a large extent' (Figure 3). Therefore, "permanent" investments in agriecosystem services and "specialization" in the provision of agro-ecosystem services of a certain type to participating farms can be considered.

In some agro-ecosystem services, the share of farms involved to a large and small extent is equal - for example in the use of manure on the farm, the provision of services to other farms and agricultural organizations, (flood protection) measures, and the hiring of workers. Therefore, a significant proportion of farms are either in the process of initially "entering" (testing, studying, adapting, etc.) in the related agro-ecosystem services, or participate in this supply as ancillary or related to the main activity.

With regard to three main types of agro-subsistence services, most of the farms involved in their supply do so to a small extent - on farm using sludge from water treatment, training of students, consumers, etc., and use and recycling of waste, composting, etc. This is a sign of either the initial entry into or exit from this activity, or the inefficiency of its further expansion (intensification) by practicing farms.

The unequal participation of farmers in the provision of agro-ecosystem services of different types and unlike degrees of involvement in such activities shows the need to take measures to improve, diversify and intensify this activity through training, information, exchange of experience, public incentives, etc. 


\section{Figure 3. Extent of participation (support) of farms in preservation or production of various types of agro-ecosystem services in Bulgaria}

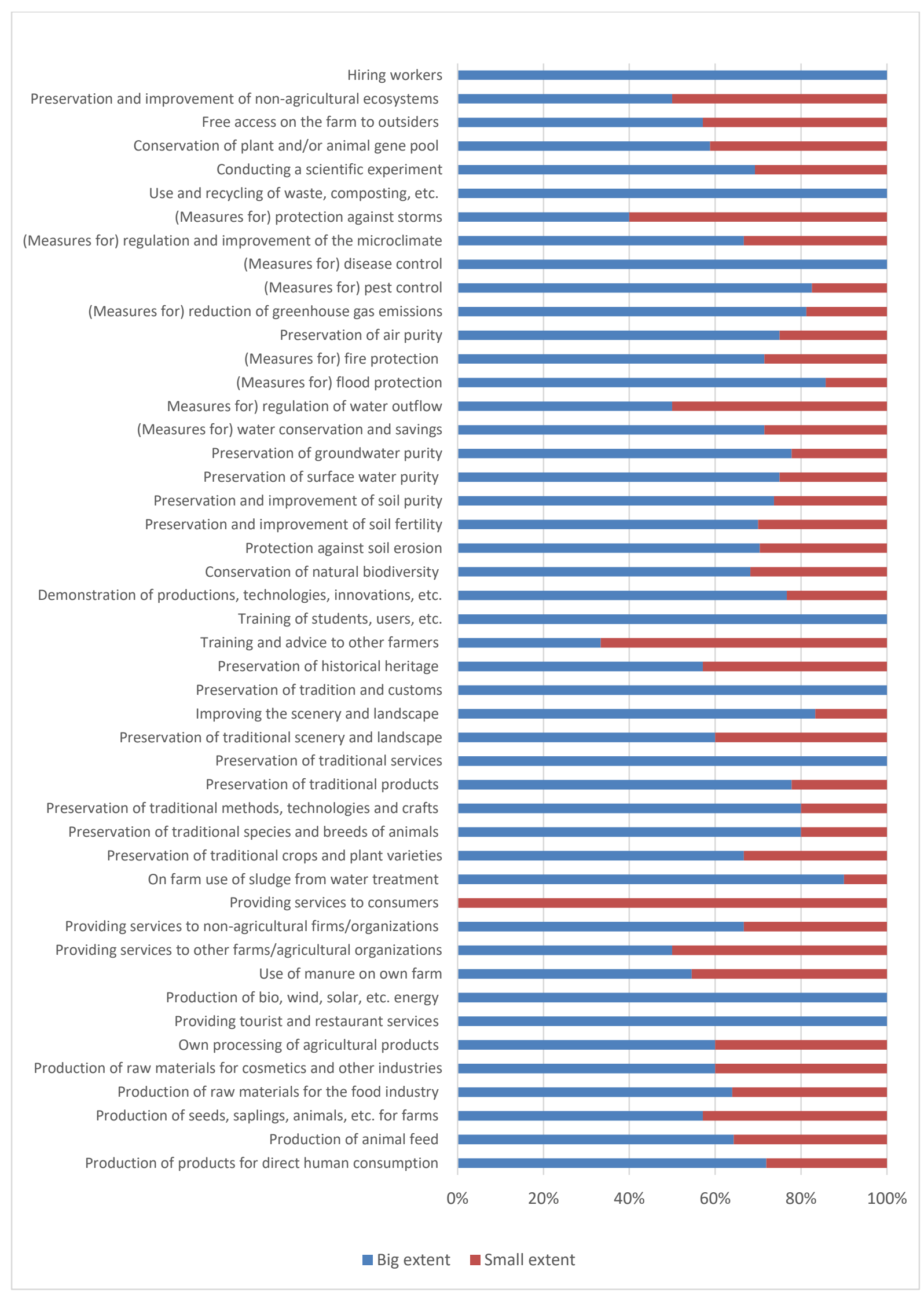

Source: Survey of agricultural producers, 2020 
There are significant differences and deviations from the average level in the participation of agricultural holdings in the preservation and supply of agro-ecosystem services in the main geographical and agricultural regions of the country (Figure 4).

North-western region surpasses the other regions in terms of share of farms contributing to agro-ecosystem services for production of raw materials for the food industry (17.5\%), own processing of agricultural products $(12.5 \%)$, provision of tourist and restaurant services $(2.5 \%)$, provision of services to end-users $(5 \%)$, and protection and improvement of soil fertility $(22.5 \%)$.

The North Central region is a champion in terms of farm participation in the preservation of traditional crops and plant varieties (16.67\%), preservation of traditional methods, technologies and crafts (10\%), preservation of traditional products (10\%), (measures for) fire protection (13.33\%) and protection of plant and /or animal gene pool (13.33\%).

The Northeast region is the largest supplier of the following agroecosystem services production of animal feed $(15.79 \%)$, production of seeds, saplings, animals, etc. for farms $(10.53 \%)$, production of raw materials for cosmetics, etc. industries $(15.79 \%)$, production of bio, wind, solar, etc. energy (5.26\%), (measures for) pest control (42.1\%), (measures for) disease control (47.37\%), conducting a scientific experiment $(5.26 \%)$, providing free access on the farm to outsiders $(15.79 \%)$ and hiring workers $(21.05 \%)$.

Southwestern region has a leading position only in terms of three agroecosystem services - production of animal feed (13.33\%), provision of services to other farms and agricultural organizations $(6.67 \%)$ and conservation of traditional species and breeds of animals $(13.33 \%)$.

South Central region is the largest producer of many agro-ecosystem services production of products for direct use by human $(82.35 \%)$, use of manure on the farm $(23.53 \%)$, preservation of traditional species and breeds of animals $(14.7 \%)$, preservation of traditional methods, technologies and crafts $(11.76 \%)$, preservation of traditional services $(14.7 \%)$, preservation of traditional scinery and landscape (11.76\%), improvement of scinery and landscape $(8.82 \%)$, preservation of tradition and customs $(8.82 \%))$, training and advice of other farmers $(11.76 \%)$, training of students, consumers, etc. $(8.82 \%)$, demonstration of productions, technologies, innovations, etc. (2.94\%), protection of natural biodiversity (26.47\%), protection against soil erosion $(29.41 \%)$, protection and improvement of soil fertility (26.47\%), protection and improvement of soil purity $(20.59 \%)$, protection of purity of surface waters $(20.59 \%)$, protection of groundwater purity $17.65 \%$, (measures for) conservation and savings of water $(14.7 \%)$, protection of air purity $(11.76 \%)$, (measures for) reduction of greenhouse gas emissions (8.82\%), (measures for) pest control $(23.53 \%)$, (measures for) control of diseases (35.29\%), (measures for) regulation and improvement of the microclimate (11.76\%), (measures for) protection against storms (8.82\%), use and recycling of waste, composting, etc. $(14.7 \%)$, conducting a scientific experiment $(5.88 \%)$, protection of plant and /or animal gene pool $(11.76 \%)$, protection and improvement of non-agricultural ecosystems $(8.82 \%)$ and employment of workers $(20.59 \%)$.

Southeast region is a leader in terms of production of products for direct human consumption $(66.67 \%)$, protection of natural biodiversity $(29.17 \%)$, protection against soil erosion $(25 \%)$, (measures to) regulate the proper outflow of water $(8.33 \%)$ and fire protection (measures) $(12.5 \%)$. 


\section{Figure 4. Share of farms involved (supporting) the preservation or production of various types of agro-ecosystem services in different regions of Bulgaria (percentages)}



Source: Survey of agricultural producers, 2020 
The large specific ecosystems in the country also differ significantly in the structure of the dominant agro-ecosystem services and in the share of the farms involved in their preservation and provision (Figure 5).

For example, the agro-ecosystem Western Stara Planina is a leader in the share of farms engaged in agro-ecosystem services related to the production of animal feed (11.54\%), own processing of agricultural products $(15.38 \%)$, provision of services to other farms and agricultural organizations (3.85\%) and provision of services to end users (7.69\%).

Another studied mountenous agro-ecosystem the Rhodope Mountains is leading in the share of agricultural producers involved in the production of products for direct human consumption $(78.95 \%)$, production of raw materials for the food industry $(21.05 \%)$, use of manure on the farm $(26.32 \%)$, preservation of traditional species and breeds of animals (10.53\%), preservation of traditional methods, technologies and crafts $(10.53 \%)$, preservation of traditional services $(21.05 \%)$, preservation of traditional scinery and landscape $(10.53 \%)$, improvement of scinery and landscape $(5.26 \%)$, preservation of historical heritage $(5.26 \%)$, education of students, consumers, etc. (5.26\%), protection of natural biodiversity $(26.32 \%)$, protection from soil erosion $(31.58 \%)$, protection and improvement of soil fertility $(26.32 \%)$, protection of air purity $(10.53 \%)$, (measures of) reduction of greenhouse gas emissions $(5.26 \%)$, (measures for) regulation and improvement of the microclimate $(15.79 \%)$, use and recycling of waste, composting, etc. $(10.53 \%)$, protection of plant and /or animal gene pool (15.79\%), and protection and improvement of non-agricultural ecosystems $(5.26 \%)$.

Agri-ecosystem Danube Plain occupies leading positions in terms of the share of farms involved in the production of raw materials for the food industry (26.92\%), provision of services to other farms and agricultural organizations (3.85\%), preservation of traditional crops and plant varieties (7.69\%), preservation of traditional species and breeds of animals (11.54\%), preservation of traditional methods, technologies and crafts $(11.54 \%)$, preservation of traditional products $(11.54 \%)$, preservation of traditions and customs $(7.69 \%)$, demonstration of productions, technologies, innovations, etc. (3.85\%), protection and improvement of soil purity (19.23\%), protection of groundwater purity (23.08\%), (measures for) storage and saving of water $(15.38 \%)$, (measures for) fire protection ( $15.38 \%$ ), protection of plant and /or animal gene pool $(15.38 \%)$, free access on the farm to outsiders $(19.23 \%)$ and hiring of workers $(11.54 \%)$.

The agro-ecosystem of Dobrudja surpasses the others in terms of production of seeds, saplings, animals, etc. for farms $(5.55 \%)$, production of raw materials for cosmetics and other industries (5.55\%), flood protection (measures) (5.55\%), fire protection (measures) $(16.67 \%)$, pests control (measures) (50\%), (measures for) disease control (55.56\%), conducting a scientific experiment $(5.56 \%)$, free access on the farm to outsiders (16.67\%) and protection and improvement of non-agricultural ecosystems $(5.56 \%)$.

The Thracian Lowland agroecosystem is at the forefront in terms of the share of participating farms in the production of products for direct human consumption (80\%), onfarm use of sludge from water treatment $(4 \%)$, conservation of natural biodiversity $(28 \%)$, conservation of surface water purity $(20 \%)$, storm protection (measures) $(4 \%)$ and employment of workers $(12 \%)$. 


\section{Figure 5. Share of farms participating (supporting) the presevation or production of various types of agro-ecosystem services in specific ecosystems of Bulgaria (percentages)}

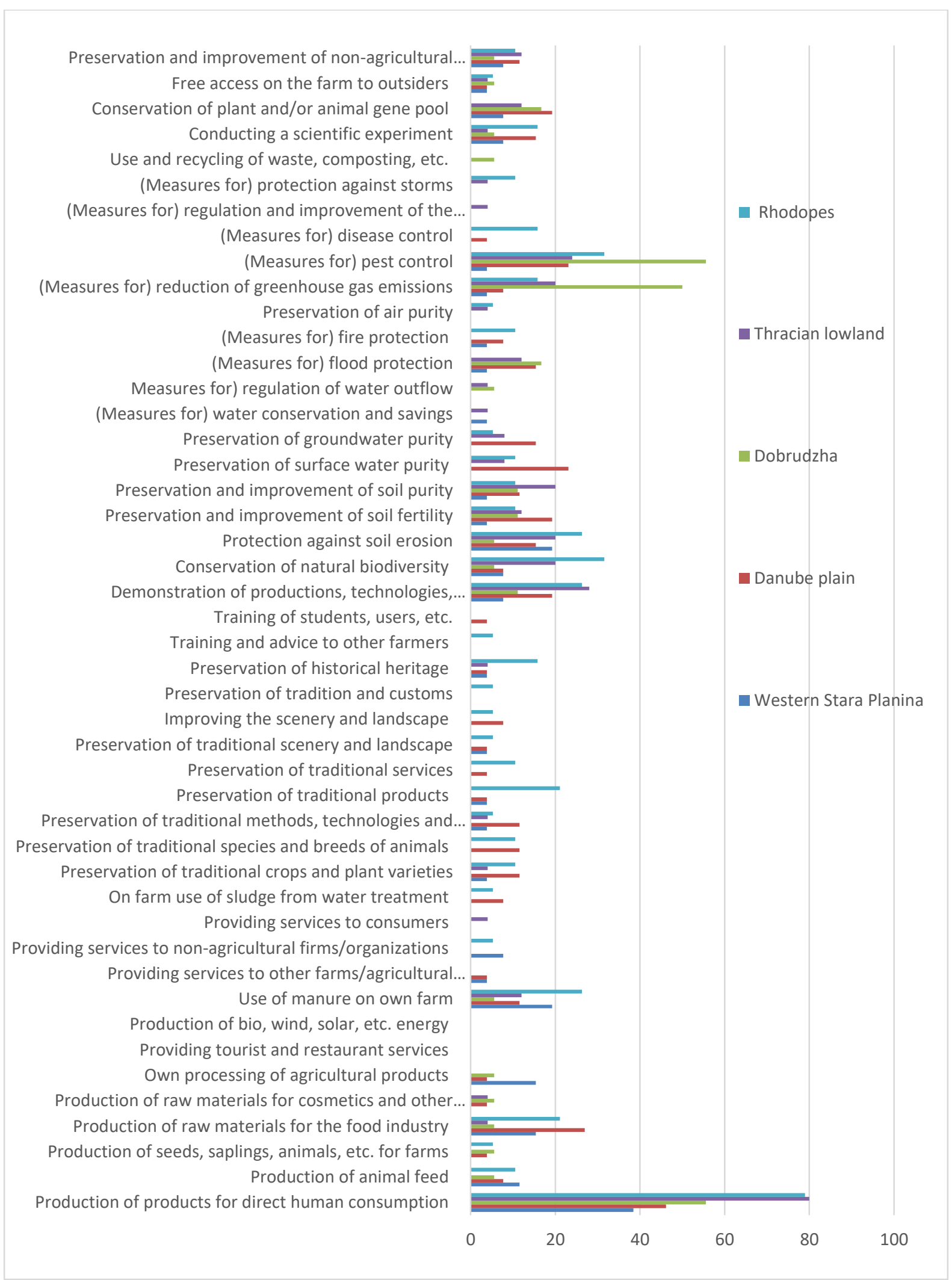

Source: Survey of agricultural producers, 2020 
Farmers in the principle ecosystems of the country are also involved to varying degrees in the preservation and production of agro-ecosystem services (Figure 6). Agroecosystems in a predominantly plain region of the country are leading in the number of participating farmers in terms of production of products for direct human consumption $(63.38 \%)$, provision of services to other farms /agricultural organizations (4.22\%), protection from soil erosion $(15.49 \%)$, protection and improvement of soil fertility $(18.31 \%)$, (measures for) pest control $(26.76 \%)$ and (measures for) disease control (30.98\%).

Agroecosystems in the plain-mountenouse regions of the country outperform the rest in terms of the share of farmers involved in the production of raw materials for cosmetics and other industries $(11.43 \%)$, preservation of traditional crops and plant varieties $(11.43 \%)$, preservation of traditional methods, technologies and crafts $(11.43 \%)$, protection of natural biodiversity (22.86\%), pest control (measures) $(25.71 \%)$ and employment of workers $(17.14 \%)$.

Agroecosystems in mostly mountainous regions of the country are in the best comparative position in terms of the inclusion of farms for preservation of traditional methods, technologies and crafts $(11.54 \%)$, preservation of traditional services $(15.38 \%)$, preservation of tradition and customs (7.69\%), preservation of historical heritage $(3.85 \%)$, education of students, consumers, etc. (7.69\%), demonstration of productions, technologies, innovations, etc. $(7.69 \%)$, (measures for) conservation and savings of water $(7.69 \%)$, (measures for) regulation and improvement of the microclimate $(11.54 \%)$ and hiring of workers $(15.38 \%)$.

The share of farms in agro-ecosystems in Protected areas and territories is superior to other types of agro-ecosystems in terms of production of animal feed (10.71\%), production of seeds, saplings, animals and others. for farms $(10.71 \%)$, production of raw materials for the food industry (25\%), provision of tourist and restaurant services $(3.57 \%)$, use of manure on the farm $(21.43 \%)$, preservation of traditional crops and plant varieties $(25 \%)$, conservation of traditional species and breeds of animals $(10.71 \%)$, conservation of traditional scinery and landscape $(10.71 \%)$, conservation of natural biodiversity $(32.14 \%)$, conservation of air purity $(14.29 \%)$, (measures for) regulation and improvement of the microclimate $(10.71 \%)$ and protection of plant and/or animal gene pool (17.86\%).

The agro-ecosystems in mountenouse regions with natural constraints occupy leading positions in the country in terms of the share of the participating farms in the production of many agro-ecosystem services - production of products for direct human consumption $(71.43 \%)$, production of animal feed $(10.71 \%)$, seed production, saplings, animals, etc. for farms $(10.71 \%)$, production of raw materials for the food industry $(32.14 \%)$, own processing of agricultural products $(17.86 \%)$, provision of tourist and restaurant services $(3.57 \%)$, use of manure on the farm $(25 \%)$, provision of services to end users $(3.57 \%)$, preservation of traditional crops and plant varieties $(17.86 \%)$, preservation of traditional species and breeds of animals $(17.86 \%)$, preservation of traditional methods, technologies and crafts $(14.28 \%)$, preservation of traditional products $(17.86 \%)$, preservation of traditional scinery and landscape $(10.71 \%)$, improvement of scinery and landscape $(10.71 \%)$, preservation of tradition and customs $(7.14 \%)$, training and advice of other farmers $(10.71 \%)$, demonstration of production, technology, innovation, etc. $(7.14 \%)$, protection of natural biodiversity $(35.71 \%)$, protection against soil erosion $(28.57 \%)$, protection and improvement of soil fertility (32.14\%), protection and improvement of soil purity (25\%), protection of purity of surface waters $(21.43 \%)$, (measures for) regulation of outflow of water $(10.71 \%)$, protection of air purity $(14.28 \%)$, (measures for) reduction of greenhouse gas emissions (10.71\%), (measures for) protection from 
storms $(7.14 \%)$, conducting a scientific experiment $(7.14 \%)$, and providing free access on the farm to outsiders $(17.85 \%)$.

\section{Figure 6. Share of farms participating (supporting) the preservation or production of various types of agro-ecosystem services in the principle agro-ecosystems of Bulgaria (percentages)}

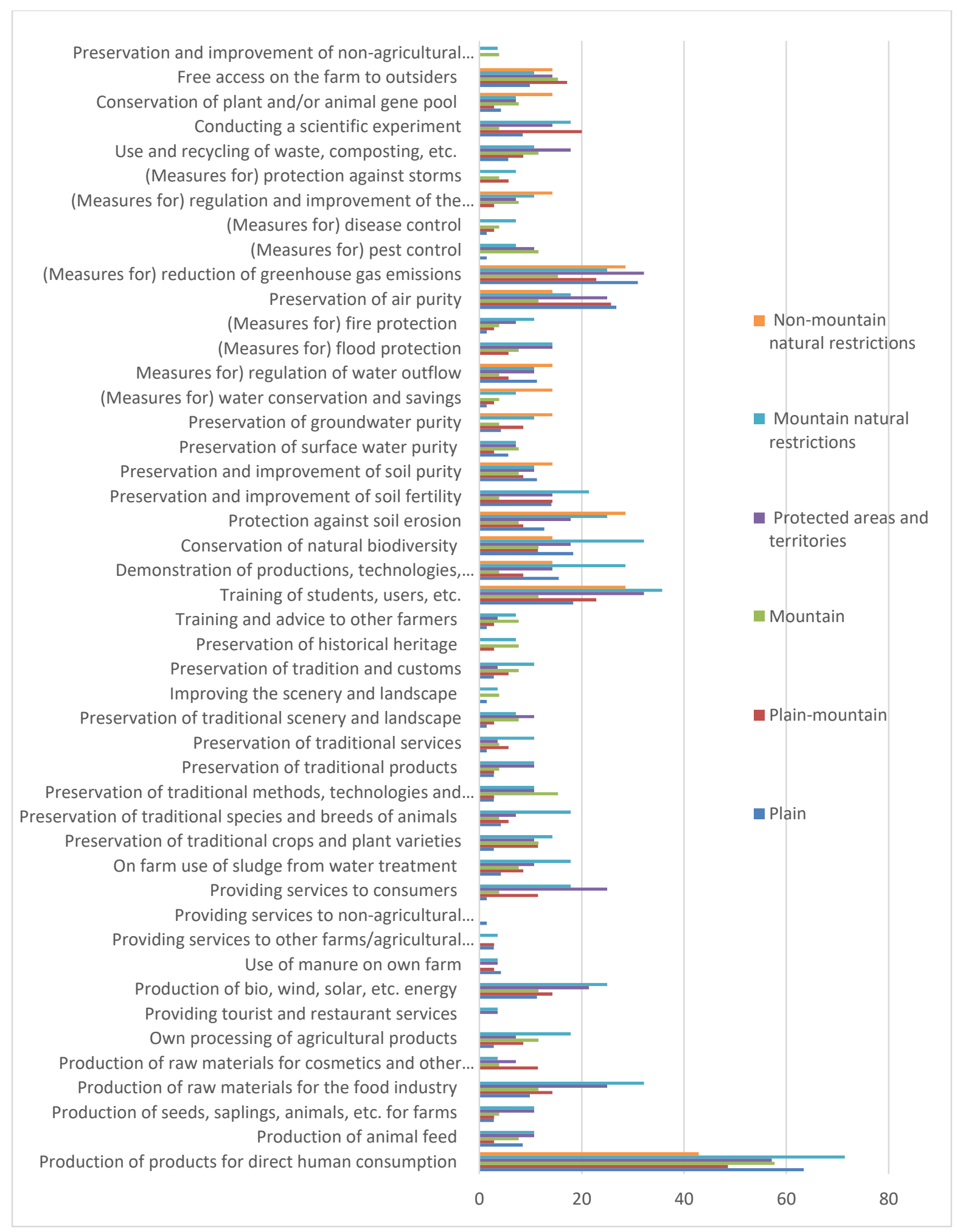

Source: Survey of agricultural producers, 2020 
On the other hand, farmers in ecosystems in non-mountainous regions with natural constraints participate in the conservation and supply of a limited range of agro-ecosystem services, outperforming other agro-ecosystems in some important areas such as conservation of natural biodiversity (28.57\%), protection and improvement of soil purity (28.57\%), protection of the purity of the groundwater (14.28\%), (measures for) regulation of the proper outflow of water (14.28\%), (measures for) protection against floods (14.28\%), (measures for) protection against fires (14.28\%), use and recycling of waste, composting, etc. (14.28\%) and protection and improvement of non-agricultural ecosystems (14.28\%).

Significant differences in the preservation and provision of services of different types in the main specific and principled ecosystems of the country, and in different geographical and agricultural areas is a sign of different potential and "specialization" in supplying the main types of services from different agro-ecosystems in the country as well as of the uneven development of this activity among the agricultural producers in the different regions and ecosystems of the country.

The share of farms with different production specialization involved in the preservation and supply of agro-ecosystem services gives a good idea of the contribution of different types of production and specific agro-ecosystems to agro-ecosystem services of different types (Figure 7). For example, agro-ecosystems with field crops contribute to a relatively smaller number of agro-system services compared to other production systems in the country. However, this specific type of agro-ecosystem is superior to the others in two respects - in terms of the share of farms involved in the production of animal feed $(21.43 \%)$ and fire protection (measures) $(21.43 \%)$.

The vegetables and mushrooms sector is leading in the country in terms of the share of participating farms in the production of products for direct human consumption (83.33\%), onfarm use of sludge from water treatment $(5.55 \%)$, (measures of) storage and savings of water (11.11\%), pest control (measures) (38.89\%) and disease control (measures) (44.44\%).

The perennials sector provides a wide variety of agro-ecosystem services, but surpasses the others only in the share of farms participating in the provision of tourist and restaurant services $(1.75 \%)$ and protection against soil erosion $(21.05 \%)$.

The grazing animals sector occupies leading positions in the country in terms of the share of farmers contributing to a number of agro-ecosystem services - production of raw materials for the food industry $(45.45 \%)$, own processing of agricultural products (18.18\%), use of manure on the farm \%), provision of services to end users $(9.09 \%)$, conservation of traditional species and breeds of animals (27.27\%), conservation of traditional services $(27.27 \%)$, protection of surface water purity $(27.27 \%)$, protection of purity of air (18.18\%), (measures for) reduction of greenhouse gas emissions $(9.09 \%)$, use and recycling of waste, composting, etc. $(18.18 \%)$, protection of plant and/or animal gene pool $(27.27 \%)$, granting free access to the territory of the farm to outsiders $(18.18 \%)$ and protection and improvement of nonagricultural ecosystems $(27.27 \%)$.

The specialized holdings in pigs, poultry and rabbits contribute to a very limited number of agro-ecosystem services, but in several respects occupy leading positions in the country where every third producer is involved in the protection and improvement of soil purity, protection of groundwater purity, (measures for ) regulating the proper flow of water, and hiring workers.

The field crops sector surpasses the others only in terms of preservation of traditional crops and plant varieties $(9.09 \%)$, while those specialized in mixed livestock for two types of 
agroecosystem services - providing services to other farms and agricultural organizations (7.69\%) and regulation and improvement of the microclimate (15.38\%).

Specialized in mix crop and livestock farms participate in the supply of a wide range of agro-ecosystem services, as a relative number of participants occupy a leading position in the production of seeds, saplings, animals, etc. for farms $(14.81 \%)$, preservation of traditional scinery and landscape $(14.81 \%)$, improvement of scinery and landscape $(11.11 \%)$, preservation of historical heritage $(7.41 \%)$, training and advice of other farmers $(14.81 \%)$, protection and improvement of soil fertility $(25.92 \%)$, (measures for) storage and saving of water $(11.11 \%)$, (measures for) protection against storms $(7.41 \%)$ and conducting a scientific experiment $(7.41 \%)$.

Farms specializing in bee families are characterized by the highest share of participants in the production of raw materials for cosmetics and other industries (10\%), preservation of traditional species and breeds of animals (30\%), preservation of traditional methods, technologies and crafts (40\%), preservation of traditional products $20 \%$, preservation of tradition and customs (20\%), demonstration of productions, technologies, innovations, etc. $(10 \%)$ and conservation of natural biodiversity (30\%).

Significant sectoral differences in the preservation and supply of services of different types are a sign of both the different "specialization" in the supply of the main types of services from farms with different specializations and the uneven development of this activity. The later requires further research into the links between specialization and agri-ecosystem services, as well as measures to expand and diversify this activity across all farm groups. 


\section{Figure 7. Share of farms with different specialization participating (supporting) the preservation or production of different types of agro-ecosystem services in Bulgaria (\%)}

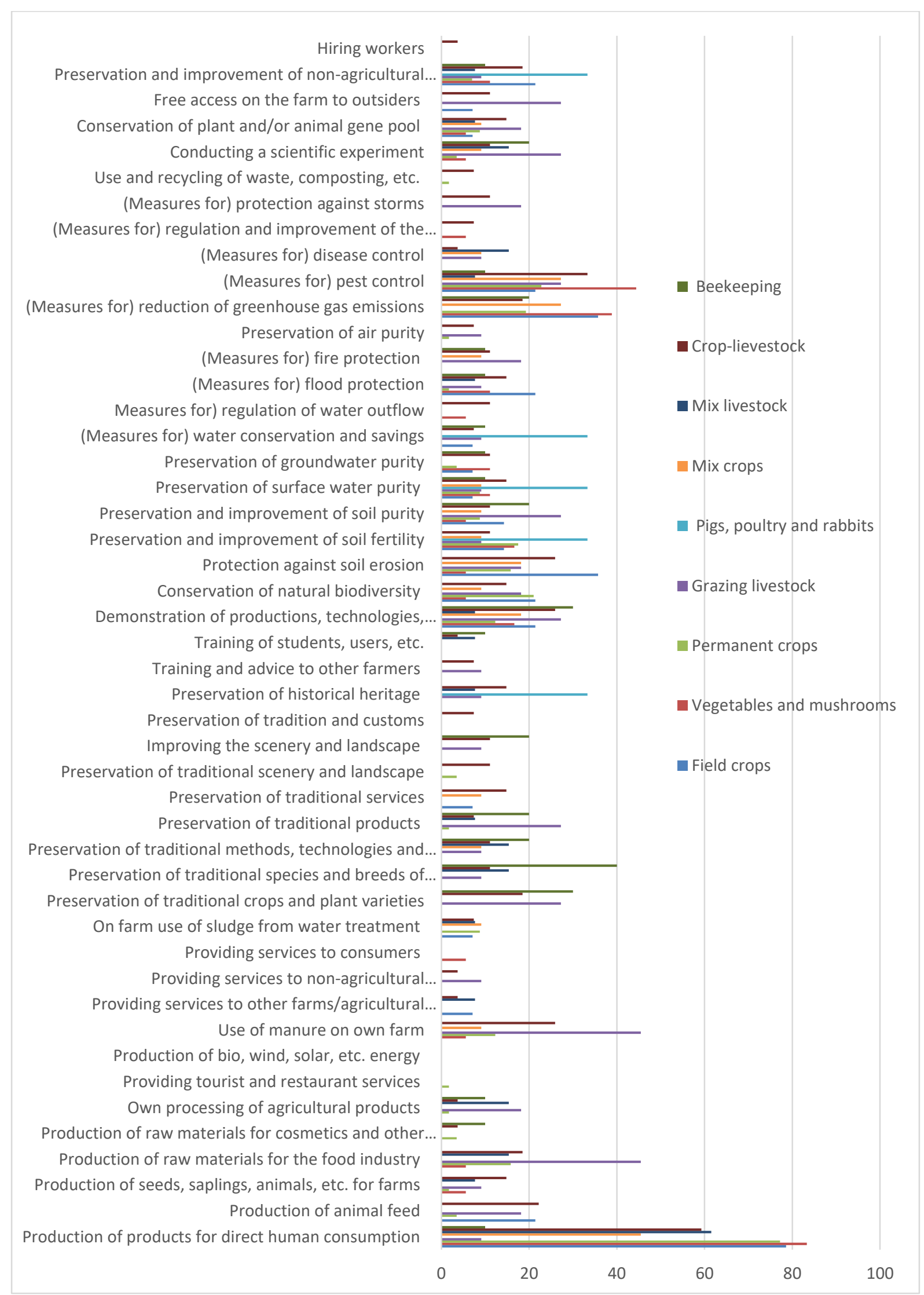

Source: Survey of agricultural producers, 2020 


\section{Socio-economic and Ecological Importance of Agroecosystem Services}

According to the majority of managers of the surveyed farms, their activities for the protection of ecosystems and their services are associated with an Increasing the economic efficiency of the farm, Increasing the ecological efficiency of the farm, Increasing the social efficiency of the farm, Improved protection of ecosystems in the region, and Improved protection of ecosystems in the country. At the same time, the majority of farms estimate that their environmentally friendly activity leads to a high increase in the economic efficiency of the farm $(59.09 \%)$, the ecological efficiency of the farm $(55.22 \%)$ and the Protection of ecosystems in the region (47.54\%).

None or very few of the surveyed farms indicate that their activities for the protection of ecosystems and their services are related to reducing the economic efficiency, environmental and social efficiency of the farm, and the protection of ecosystems in the region and the country. However, a significant share of farm managers believe that their efforts and costs to protect ecosystems and ecosystem services do not lead to changes in the social efficiency of the farm $(36.17 \%)$ and improved protection of ecosystems in the country $(37.78 \%)$.

\section{Figure 8. Efficiency of the farms' activity for protection of ecosystems and their services in Bulgaria (percentages)}

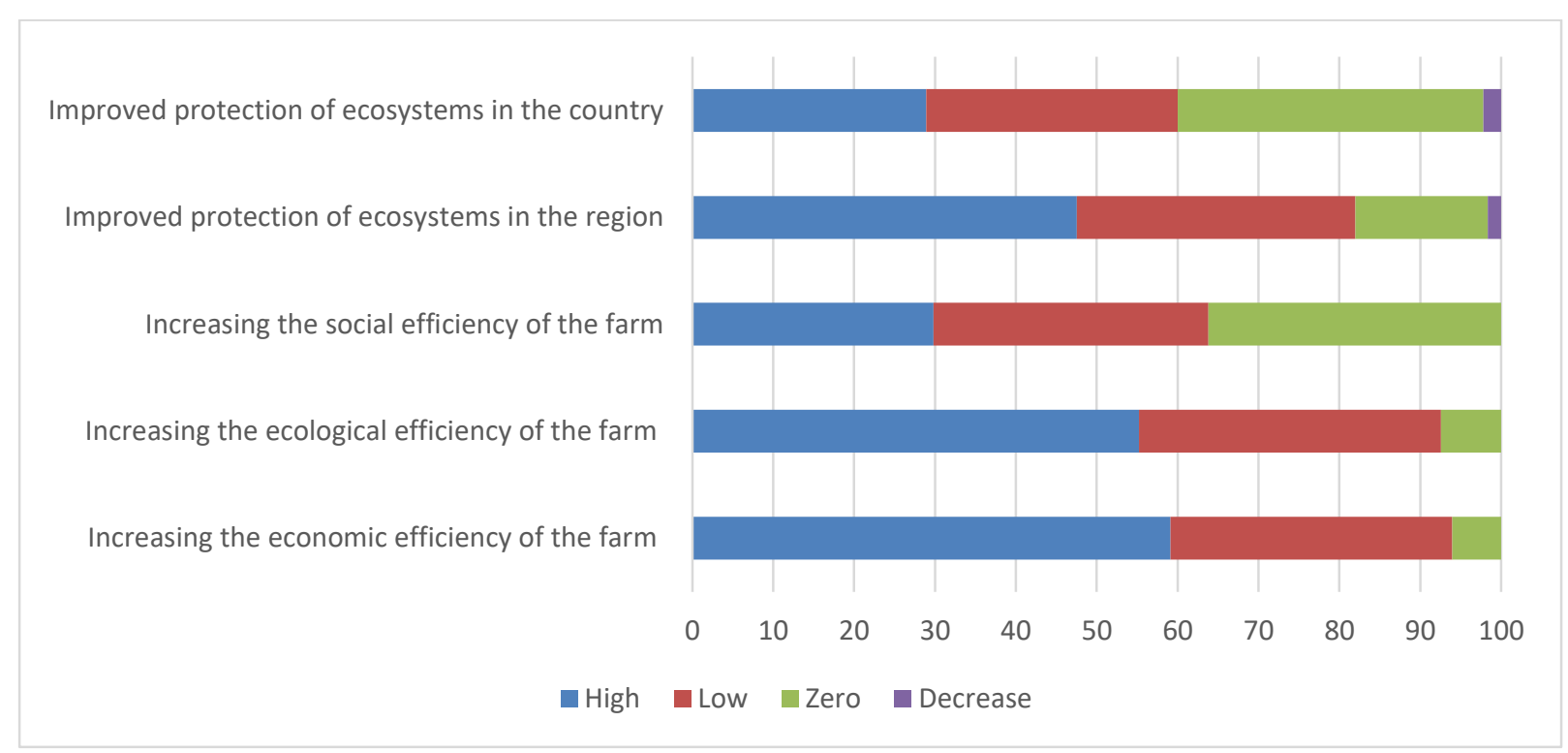

Source: Survey of agricultural producers, 2020

There is a significant differentiation in the level of efficiency of farm activities related to the protection of ecosystems and ecosystem services (Figure 9). 


\section{Figure 9. Share of farms with a high efficiency of activity for protection of ecosystems and their services in Bulgaria (percentages)}

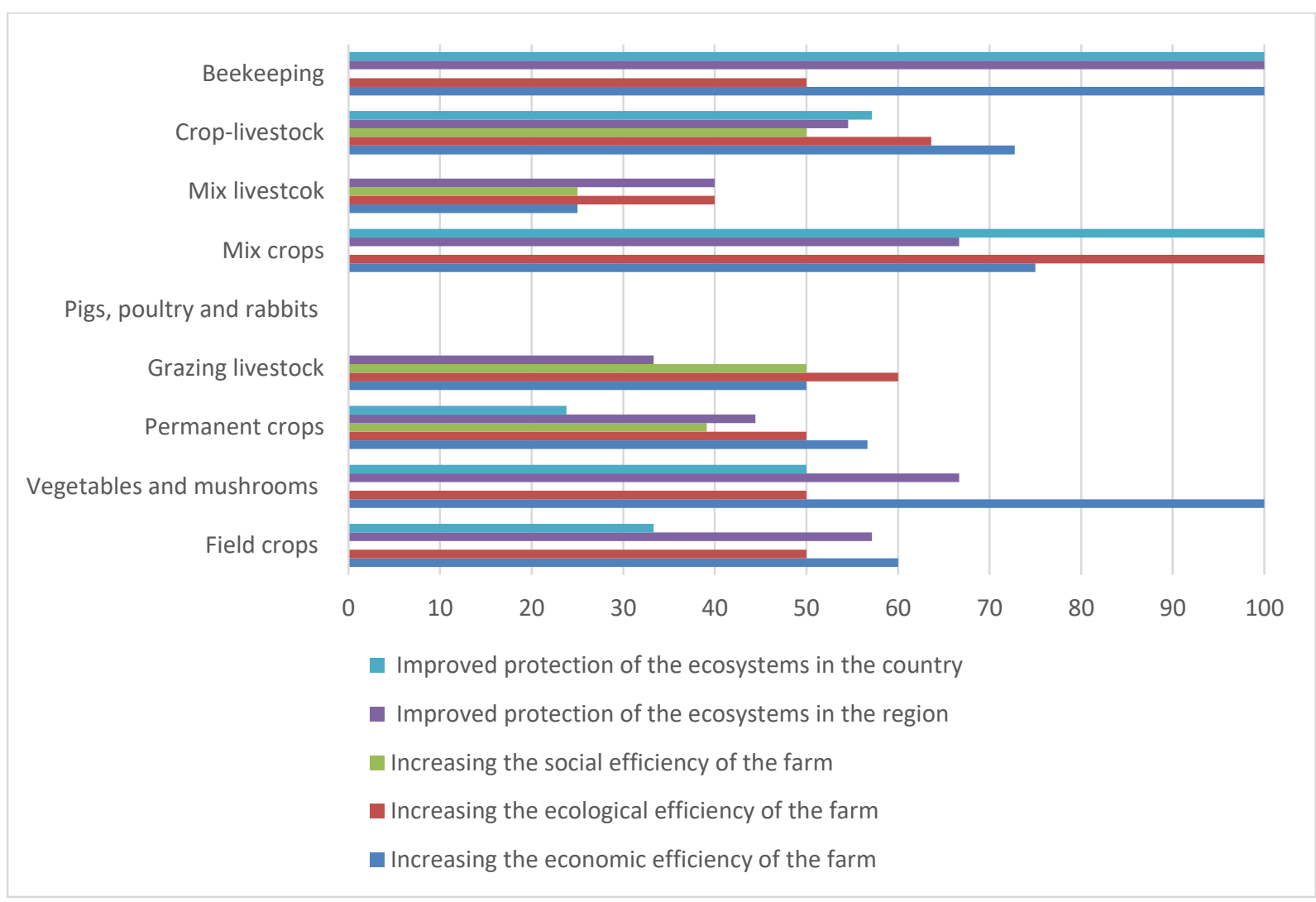

Source: Survey of agricultural producers, 2020

High increase of the economic efficiency of the farm related to the protection of ecosystems and ecosystem services is most noted in the farms specialized in Field crops (60\%), Vegetables and mushrooms (100\%), Mixed crop production (75\%), Mix crop-livestock production (72.73\%) and Bee families (100\%), and the least in those in Mixed livestock (25\%) and Pigs, poultry and rabbits (0).

High increase of the ecological efficiency of the holdings' activity for protection of ecosystems and ecosystem services is reported by all from Mixed crops farms, and the majority of those with Grazing animals (60\%) and Crop and animal husbandry (63.64\%). The lowest share of farms with similar growth is in those specialized in Mixed Livestock (40\%) and Pigs, poultry and rabbits $(0)$.

High Increasing the social efficiency of the holdings's activity for protection of ecosystems and ecosystem services is registered by every second farm specializing in Herbivores and Corp-livestock, a smaller part of those in Perennial crops (39.13\%) and Mixed livestock $(25 \%)$, and from none of the other categories of holdings.

High improved protection of ecosystems in the region, related to the activity of farms for protection of ecosystems and ecosystem services is achieved mostly by the farms in Field crops (57.14\%), Vegetables and mushrooms (66.67\%), Mixed crop growing (66.67\%), and Bee families (100\%), and relatively the least of those with Grazing animals (33.33\%) and Pigs, poultry and rabbits $(0)$.

High improved protection of ecosystems in the country related to the activities of farms for protection of ecosystems and ecosystem services is reported by all those specializing in 
Mixed crops and Bee families, and most of those in Mix crop-animal husbandry (57.14\%). The share of farms with a similar effect is the lowest in those specialized in field crops $(33.33 \%)$ and perennials $(23.81 \%)$, and in none of them in grazing animals, pigs, puultey and rabbits, and mixed animal husbandry.

The vast majority of farm managers estimate that the effect of the overall activity of the farm is positive in terms of soils $(73.95 \%)$, biodiversity $(62.3 \%)$, landscape $(51.11 \%)$ and economic development of the region (60.82\%). Also, the majority of managers believe that the effect is positive in terms of Air (48.54\%), Surfacewaters (36.2\%), Groundwaters (47.47\%), Climate $(38.37 \%)$, Traditional breeds, varieties, products, technologies. (44.68\%), and Social development of the region $(48.89 \%)$, as a relatively smaller part consider a positive effect in terms of Local culture, traditions, customs, education $(28.39 \%)$.

However, the share of managers who believe that the whole activity of their farm is not associated eith any effect on the individual elements of the ecosystem - Soils (14.29\%), Air (29.13\%), Surfacewaters ( 34\%), Groundwaters (26.26\%), Biodiversity (16\%), Landscape (17.78\%), Climate (23.26\%), Traditional breeds, varieties, products, technologies $(20.21 \%)$, Local culture, traditions, customs, education (32.1\%), Economic development of the region $(16.49 \%)$ and Social development of the region (18.89\%).

In addition, a significant part of managers do not know the effect of the overall activity of agriculture on various elements of the ecosystem - Soils (10.92\%), Air (20.39\%), Surfacewaters (28.7\%), Groundwaters (26.26\%), Biodiversity (21.7\%), Landscape (30\%), Climate $(34.88 \%)$, Traditional breeds, varieties, products, technologies (31.91\%), Local culture, traditions, customs, educated $(37.04 \%)$, Economic development of the region (19.59\%), and Social development of the region (27.78\%). The later requires both deepening and expanding independent assessments of the effects of farming on the individual components of ecosystems, and better informing farmers about their negative and /or positive contribution to environmental protection and ecosystem services. 
Figure 10. Effect of the overall activity of the agricultural holding on the different elements of the ecosystem in Bulgaria

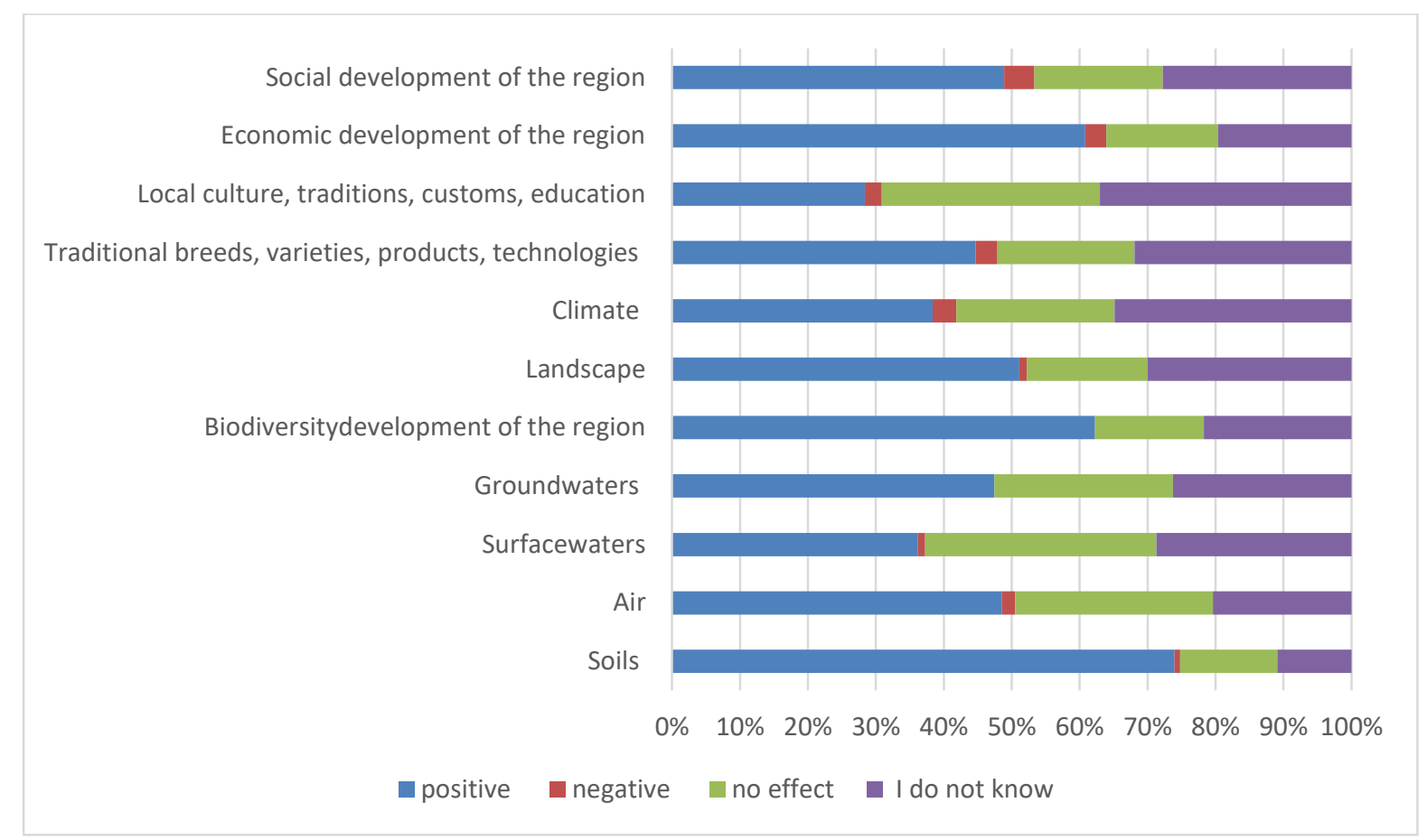

Source: Survey of agricultural producers, 2020

Just over half of the surveyed managers assess the importance of their activities for the protection of agro-ecosystems and agro-ecosystem services as High for their farm $(50.62 \%)$ and $46.91 \%$ High for themselves (Figure 10). A significant share of managers also believe that their activities for the protection of agro-ecosystems and agro-ecosystem services are of high importance for the region of their farm (27.16\%). There is also a significant number of managers who believe that this activity has a high environmental value (14.81\%) and value for future generations $(13.58 \%)$. A relatively smaller part of the managers believe that such activity is of High importance for the community in the region (7.41\%), High market value $(5.56 \%)$ and High economic value $(6.17 \%)$.

At the same time, an insignificant share of managers are convinced that their activity for protection of agro-ecosystems and agro-ecosystem services has a High contract value $(1.23 \%)$, and a High social value $(2.47 \%)$ or is Without any value $(1.23 \%)$, as none of the respondents believes that this activity has a High cultural value. 
Figure 11. Assessment of farm managers of the importance of their activity for protection of agro-ecosystems and agro-ecosystem services in Bulgaria (percentages)

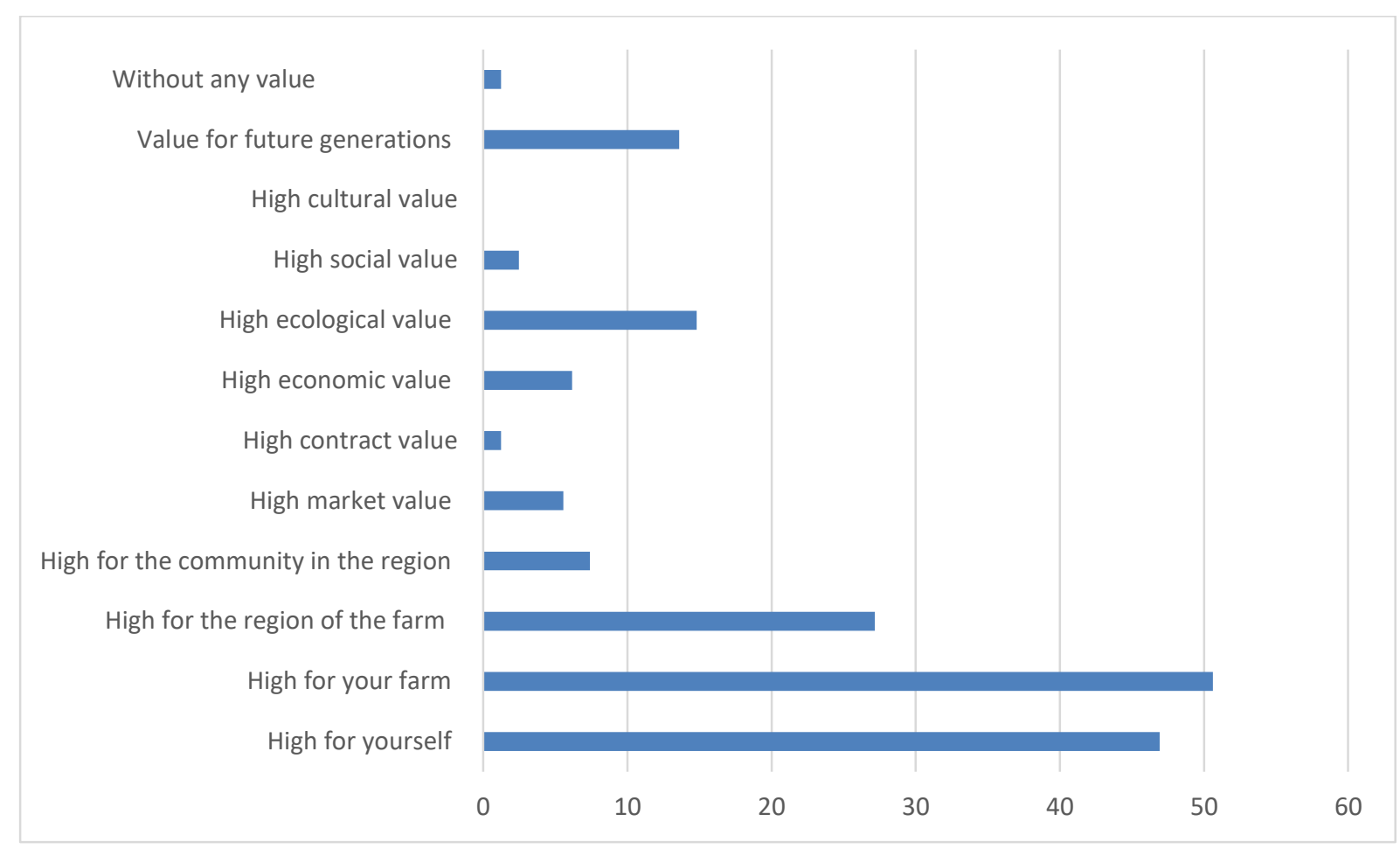

Source: Survey of agricultural producers, 2020 


\section{Conclusion}

It is well known that agricultural production makes a significant contribution to the conservation, restoration and enhancement of ecosystems and their services, but also is associated with negative effect and their degradation and demolition (,agricultural disservices" $\left.{ }^{6}\right)$. Therefore, services related to agricultural production and agro-ecosystems are among the most intensively studied, mapped, evaluated, regulated and stimulated.

Our study has tried to fill the gap and give initial insighst on great variety of agricultural services and ther importance for the farm, region, other ecosystems and agents in Bulgaria. It found out that there are significant differences in the participation and contribution of agricultural holdings in the protection and provision of agro-ecosystem services in the variouse specific and principled ecosystems of the country, and major subsectors of agricultural production. The later requires special measures to improve, diversify and intensify this activity of farmers through training, information, exchange of experience, public incentives and support, etc.

Analyzes of the structure and importance of agro-ecosystem services in the country are to be expanded by improving the accuracy and representativeness of the information by increasing the number of surveyed farms, avoiding "douple" accounting, applying statistical methods to verify reliability, special "training" of and those involved in surveys, applying direct field measurmentsa experts and stakeholders involvments etc. This requires closer cooperation with agricultural producers' organizations, agricultural advisory and extension system, and all stakeholders, as well as improving the official system for collecting agricultural, agroeconomic and agri-environmental data in the country. 


\section{References:}

Башев Х. (2009): Управление на услугите на агро-екосистемите, Икономика и управление на селското стопанство № 6, 3-20.

Башев Х. (2014): Екоуправление в селското стопанство, Икономическа мисьл, бр.1, 29-55.

Башев Х., Б. Иванов, Д. Митова, П. Маринов, К. Тодорова, А. Митов (2020): ПОДХОД ЗА ОЦЕНКА НА УПРАВЛЕНИЕТО НА УСЛУГИТЕ НА АГРОЕКОСИСТЕМИТЕ В БЪЛГАРИЯ, ИАИ, ISВN 978-954-8612-24-1

Башев Х. (2020): ПОДХОД ЗА АНАЛИЗ И УСЪВЪРШЕНСТВАНЕ НА УПРАВЛЕНИЕТО НА УСЛУГИТЕ НА АГРО-ЕКОСИТЕМИТЕ, ИКоНОМИКа и УПравЛение на селското стопанство, бр. 3, 27-48.

Башев Х. (2020): ДЕФИНИРАНЕ, АНАЛИЗИРАНЕ И УСЪВЪРШЕНСТВАНЕ НА УПРАВЛЕНИЕТО НА УСЛУГИТЕ НА АГРО-ЕКОСИТЕМИТЕ, ИКОНОМИчесКа МИСЪЛ, бр. 4, 3-30.

ИАОС (2020): Екосистемни услуги, Испълнителна агенция за околна среда.

Йорданов Я., Д. Михалев, В. Василев, С. Братанова- Дончева, К. Гочева, Н. Чипев (2017): Методика за оценка и картиране на състоянието на земеделските екосистеми и техните услуги в българия, ИАОС.

Казакова Я. (2016): Земеделие с висока природна стойност (обучение, иновации, знания), УНCC.

Недков С. (2016): КОНЦЕПЦИЯ ЗА Екосистемни услуги, Презентация, работна среща 31 май 2016г.

Николов С. (2018): Екосистемни услуги и тяхното оценяване - кратък преглед, Journal of the Bulgarian Geographical Society, Volume 39, 51-54.

Тодорова К. (2017): Управление на риска от наводнения чрез екосистемни услуги от земеделските стопанства, Дисертация, УНСC, WWF (2019): Екосистемите и техните „услуги”, WWF.

Чипев Н., Св. Братанова - Дончева, К. Гочева, М. Жиянски, М. Мондешка, Я. Йорданов, И. Апостолова, Д. Сопотлиева, Н. Велев, Е. Рафаилова, Й. Узунов, В. Карамфилов, Радка Фикова, Ст. Вергиев (2017): Методологична рамка за оценка и картиране на състоянието на екосистемите и екосистемните услуги в българия ръководство за мониторинг на състоянието и развитието на екосистемите и екосистемните услуги, ИАОС.

Bachev H. (2009): Governing of Agro-ecosystem Services. Modes, Efficiency, Perspectives, VDM Verlag.

Bachev H. (2009): MODES OF GOVERNANCE OF ECOSYSTEM SERVICES, IUP Journal of Governance \& Public Policy 4.

Bachev H. (2009): Understanding Efficiency of Agrarian Organization, Annals of the University of Petrosani - Economics 9 (1), 27-42.

Bachev H. (2010): Framework for Analysis of Agrarian Contracts, Management Research and Practice 2 (1), 39-66.

Bachev H (2011): Management of Agro-Ecosystem Services: Framework of Analysis, Case of Bulgaria, in J. Daniels (editor), Advances in Environmental Research. Vol. 17, New York: Nova Science, 119-164.

Bachev H. (2012): Governing of Agro-Ecosystem Services in Bulgaria, in A. Rezitis (editor), Research Topics in Agricultural and Applied Economics, Vol. 3, Bentham Science Publisher, 94-129.

Bachev H. (2013): New Approach for Assessing and Improvement of Environmental Management and Strategies in Agri-business, Global Journal of Management And Business Research, Volume 13, Issue 7.

Bachev H. (2013): Risk Management in Agri-food Sector, Contemporary Economics, Vol. 7 (1), 4562. 
Bashev H. (2016): Defining and assessment of sustainability of farms, Economic Studies Journal, $158-188$.

Bachev H. (2020): Defining, analyzing and improving the governance of agroecosystem services, Economic Thought, 4, 31-55.

Bachev H. (2020): Understanding and improving the governance of ecosystem services: The case of agriculture, Journal of Economics Bibliography, Volume 7, Issue 3, 170-195.

Bachev H. (2020): Understanding, evaluating and improving the system of governance of agroecosystem service, Exploratory Environmental Science Research,Vol.1, Issue 1, 96-114.

Bachev H. (2020): About the Governance of Agro-ecosystem Services, Open Journal of Economics and Commerce, Volume 3, Issue 1, 24-36.

Bachev H. and D. Terziev (2019): Sustainability of Agricultural Industries in Bulgaria, Journal of Applied Economic Sciences, Volume 14, Issue 1.

Bachev H., B.Ivanov and A.Sarov (2020): Unpacking Governance Sustainability of Bulgarian Agriculture, Икономически изследвания, 6, 106-137.

Bachev H., B.Ivanov, A. Sarov (2020): Why and How to Assess the "Governance" Aspect of Agrarian Sustainability - The Case of Bulgaria, Agricultural Research Updates. Volume 30, Editors Prathamesh Gorawala and Srushti Mandhatri, Nova Science Publisher, 49-104.

Bachev H. (2021): ASSESSING AND IMPROVING THE GOVERNANCE OF AGROECOSYSTEM SERVICES, Agricultural Research Updates. Volume 33.

Bachev H., B.Ivanov and A.Sarov (2021): Assessing Governance Aspect of Agrarian Sustainability in Bulgaria, Bulgarian Journal of Agricultural Sciences, 2.

Boelee, E. (Editor) (2013): Managing water and agroecosystems for food security, CABI.

De Groot R., Wilson M, Boumans R. (2002): A typology for the description, classification and valuation of ecosystem functions goods services. Ecol Econ 41:393-408

EC (2018): Proposal for a REGULATION OF THE EUROPEAN PARLIAMENT AND OF THE COUNCIL establishing rules on support for strategic plans to be drawn up by Member States under the Common agricultural policy (CAP Strategic Plans) and financed by the European Agricultural Guarantee Fund (EAGF) and by the European Agricultural Fund for Rural Development (EAFRD) and repealing Regulation (EU) No 1305/2013 of the European Parliament and of the Council and Regulation (EU) No 1307/2013 of the European Parliament and of the Council, European Commission, Brussels, 1.6.2018

EEA (2015): Ecosystem services in the EU, European Environment Agency.

FAO (2016): Mainstreaming ecosystem services and biodiversity into agricultural production and management in East Africa, Technical guidance document, FAO.

Fremier A., F. DeClerck, N.Bosque-Pérez, N. Carmona, R, Hill, T. Joyal, L. Keesecker, P. Klos, A. Martínez-Salinas, R. Niemeyer, A. Sanfiorenzo, K. Welsh, J. Wulfhorst (2013): Understanding Spatiotemporal Lags in Ecosystem Services to Improve Incentives, BioScience Vol. 63 No. 6.

Gao H., T. Fu, J. Liu, H. Liang and L. Han (2018): Ecosystem Services Management Based on Differentiation and Regionalization along Vertical Gradient, China, Sustainability, 10, 986

Garbach K., J. Milder, M Montenegroand, F. DeClerck (2014): Biodiversity and Ecosystem Services in Agroecosystems, Elsevier.

Gemmill-Herren B. (2018): Pollination Services to Agriculture Sustaining and enhancing a key ecosystem service, Routledge.

Grigorova Y. \& Kazakova Y. (2008): High Nature Value farmlands: Recognizing the importance of South East European landscapes, Case study report, Western Stara Planina, WWF (EFNCP).

Habib T., S. Heckbert, J. Wilson, A.Vandenbroeck, J. and D. Farr (2016): Impacts of land-use management on ecosystem services and biodiversity: an agent-based modelling approach. PeerJ 4:e2814.

INRA (2017): A framework for assessing ecosystem services from human-impacted ecosystems. EFESE, 
Koteva N., H. Bachev (2011): A study on competitiveness of Bulgarian farms, Economic Tought, Volume 7, 95-123.

Kanianska R. (2019): Agriculture and Its Impact on Land-Use, Environment, and Ecosystem Services, INTECH.

Marta-Pedroso C., L. Laporta, I. Gama, T. Domingos (2018): Economic valuation and mapping of Ecosystem Services in the context of protected area management, One Ecosystem 3: e26722,

MEA (2005): Millennium Ecosystem Assessment, Ecosystems and Human Well-being, Island Press, Washington, DC.

Novikova A., L. Rocchi, V. Vitunskienè (2017): Assessing the benefit of the agroecosystem services: Lithuanian preferences using a latent class approach, Land Use Policy, Vol. 68, 277-286.

Nunes P., P. Kumar, T. Dedeurwaerdere (2014): Handbook on the Economics of Ecosystem Services and Biodiversity, Edward Elgar, Cheltenham.

Petteri V., D. D’Amato, M. Forsius, P. Angelstam, C. Baessler, P. Balvanera, B. Boldgiv, P. Bourgeron, J. Dick, R. Kanka, S. Klotz, M. Maass, V. Melecis, P. Petrik, H. Shibata, J. Tang, J. Thompson and S. Zacharias (2013): Using long-term ecosystem service and biodiversity data to study the impacts and adaptation options in response to climate change: insights from the global ILTER sites network, Current Opinion in Environmental Sustainability 2013, 5:53-66.

Power, A. (2010): Ecosystem services and agriculture: Tradeoffs and synergies. Philos. Trans. R. Soc. Lond. B Biol. Sci. 365, 2959-2971.

Scholes R, B. Reyers, R. Biggs, M. Spierenburg and A. Duriappah (2013): Multi-scale and cross-scale assessments of social-ecological systems and their ecosystem services, Current Opinion in Environmental Sustainability, 5:16-25.

Todorova K. (2017): Adoption of ecosystem-based measures in farmlands - new opportunities for flood risk management, Trakia Journal of Sciences, Vol. 15, 1, 152-157.

Tsiafouli M., E. Drakou, A. Orgiazzi, K. Hedlund and K. Ritz (2017): Optimizing the Delivery of Multiple Ecosystem Goods and Services in Agricultural Systems, Frontiers in Ecology and Evolution, vol.5, art. 9715

UN (2005). The Millennium Development Goals Report. United Nations, New York.

Van Oudenhoven, A. (2020): Quantifying the effects of management on ecosystem services, https://www.wur.nl/en/show/Quantifying-the-effects-of-management-on-ecosystemservices.htm

Wang S., B. Fu, Y. Wei, C. Lyle (2013): Ecosystem services management: an integrated approach, Current Opinion in Environmental Sustainability, 5:11-15.

Wood S., D. Karp, F. DeClerck, C. Kremen, S. Naeem, C. Palm (2015): Functional traits in agriculture: agrobiodiversity and ecosystem services, Trends in Ecology \& Evolution, 1-9.

Zhan J. (Editor) (2015): Impacts of Land-use Change on Ecosystem Services, Springer. 